\title{
Editorial Note-Darwin and the origin of life
}

\author{
Alan W. Schwartz
}

(C) The Author(s) 2009. This article is published with open access at Springerlink.com

This Darwin year-celebrating the 200th anniversary of Charles Darwin's birth as well as the 150th anniversary of the publication of The Origin of Species - comes at an especially opportune moment. Rarely have the reality and the significance of evolution been so often misconstrued and challenged. The popular literature abounds with ill-informed attacks which attempt to "prove" that evolution cannot explain biological complexity, let alone the origin of life itself. Darwin too was fascinated by the question of how the first common ancestor of all life on earth came into existence, but usually refrained from speculating on the subject. In an invited paper in this issue Juli Peretó, Jeffrey Bada and Antonio Lazcano explore the available evidence relating to Darwin's thinking on the topic.

Open Access This article is distributed under the terms of the Creative Commons Attribution Noncommercial License which permits any noncommercial use, distribution, and reproduction in any medium, provided the original author(s) and source are credited.

A. W. Schwartz $(\bowtie)$

Hilversum, The Netherlands

e-mail: alan@sci.ru.nl 